\title{
PENEGAKAN PASAL 504 KUHP DIHUBUNGKAN DENGAN PERATURAN PEMERINTAH NOMOR 31 TAHUN 1980 TENTANG PENANGGULANGAN GELANDANGAN DAN PENGEMIS
}

\author{
oleh: \\ Dimas Fadel Supeno \\ Cecep Sutrisna
}

\begin{abstract}
ABSTRAK
Permasalahan gelandangan dan pengemis merupakan salah satu permasalahan sosial yang sulit untuk ditangani. Banyaknya jumlah gelandangan dan pengemis yang kerap kali terlihat memadati setiap perempatan dan ruas - ruas jalan utama bukan saja tidak sedap dipandang, melainkan menjadi isu serius yang perlu dicarikan jalan pemecahannya bersama. Selama ini keberadaan gelandangan dan pengemis (Gepeng) merugikan masyarakat dan negara. Negara dirugikan karena sumber daya manusia yang semula diharapkan dapat mandiri, produktif, dan mampu membangun negara menjadi gelandagan dan pengemis yang menggantungkan hidupnya kepada orang lain, tidak mempunyai kehidupan yang layak, dan tidak dapat mencukupi kebutuhan secara mandiri, serta kehidupannya bebas yang tidak mematuhi norma-norma. tidak sejalan dengan cita-cita nasional karena mereka menjadi beban Negara, ada beberapa faktor penyebab pengemisan tinggi dan upaya penanggulangan nya juga upaya pemerintah dalam penegakan hukum terkait pengemisan dan gelandangan. Hasil penelitian menyimpulkan bahwa pengemisan merupakan tanggung jawab pemerintah dan para penegak hukum, serta peranserta masyarakat sebagai pemberi sumbangan. dalam PP No. 31 tahun 1980 tentang penanggulangan gelandangan dan pengemis sudah di jelaskan secara rinci terkait cara memberantas gelandangan dan pengemis, tinggal bagaimana penegakan nya, yaitu dengan pengawasan dan razia yang dilakukan secara berkala serta penyuluhan dan pembinaan terhadap pengemis agar pengemis dan gelandangan jera untuk melakukan pengemisan dan pergelandangan lagi, sebab terjadinya gelandangan dan pengemis dapat dibedakan menjadi dua faktor penyebab, yaitu faktor internal dan faktor eksternal. Faktor internal meliputi sifat-sifat malas, tidak mau bekerja, mental yang tidak kuat, adanya cacat fisik ataupun cacat psikis. Sedangkan faktor eksternal meliputi faktor sosial, kultural, ekonomi, pendidikan, lingkungan, agama dan letak geografis.
\end{abstract}

Kata kunci: tindak pidana pengemisan, penegakan hukum, penanggulangan pengemis.

\section{PENDAHULUAN}

\section{Latar Belakang}

Salah satu permasalahan yang dihadapi oleh pemerintah/negara indonesia adalah kemiskinan, Negara Indonesia adalah negara hukum. Negara Indonesia telah memiliki landasan yuridis yang kuat dalam peranannya melaksanakan pembangunan.Pancasila sebagai ideologi bangsa dan sebagai pandangan hidup bangsa Indonesia telah memberikan arah dan tujuan bagi pembangunan yang diharapkan, yakni menuju keadilan sosial bagi seluruh rakyat Indonesia seutuhnya.

Kesejahteraan sosial, yang ingin diwujudkan dalam negara Republik Indonesia, telah pula diatur dalam Pasal 33 ayat (3) Undang-undang Dasar 1945 yang berbunyi, Bumi, air dan kekayaan alam yang terkandung di dalamnya dikuasai oleh negara dan dipergunakan untuk sebesar-besar kemakmuran rakyat'. Hal ini mewujudkan bahwa kekayaan alam yang ada di Indonesia haruslah dipergunakan bagi terwujudnya kemakmuran rakyat. Sehubungan dengan 
masalah kemiskinan, pada Pasal 34 UUD 1945 secara eksplisit menegaskan bahwa, fakir miskin dan anak-anak terlantar dipelihara oleh negara'. Mengingat bahwa tujuan dibentuknya negara Republik Indonesia adalah untuk memajukan kesejahteraan umum sebagaimana tercantum dalam Pembukaan UUD 1945') Maka konsekuensinya negara atau pemerintah tidak dapat melepaskan tanggung jawabnya untuk menanggulangi masalah kemiskinan. pembangunan di segala bidang kehidupan guna mewujudkan kesejahteraan sosial. Hukum diharapkan mampu memfungsikan dirinya untuk mengatasi atau bahkan memberantas kemiskinan yang masih diderita oleh sebagian masyarakat kita. hukum dapat dijadikan sebagai alat atau sarana untuk mengadakan rekayasa sosial (A Tool Of Social Engineering) dalam upaya menanggulangi masalah kemiskinan ${ }^{2}$ ), dewasa ini pemerintah masih belum mampu menghadapi atau menyelesaikan permasalahan tersebut, padahal hampir setiap pemimpin Negara Indonesia selalu membawa kemiskinan sebagai misi utama mereka disamping misi-misi yang lain.

Undang-Undang Dasar 1945 adalah Landasan konstitusional Negara Kesatuan Republik Indonesia. Para pendiri negeri ini telah merumuskannya, sejak Bangsa Indonesia Merdeka dari jajahan para kolonialisme. UUD 1945 adalah sebagai hukum dasar tertinggi dalam penyelenggaraan kehidupan berbangsa dan bernegara. UUD 1945 telah di amandemen empat kali pada tahun 1999, 2000, 2001, dan 2002 yang telah menghasilkan rumusan Undang - Undang Dasar yang jauh lebih kokoh menjamin hak konstitusional warga negara, UUD 1945 Pasal 34 ayat 1 saling berhubungan, dalam UUD 1945 Pasal 34 Ayat 1 yang berbunyi Fakir Miskin dan anak - anak yang terlantar dipelihara oleh negara. UUD 1945 Pasal 34 Ayat 1 tersebut mempunyai makna bahwa gepeng dan anak - anak jalanan dipelihara atau diberdayakan oleh negara yang dilaksanakan oleh pemerintah. Fakir ialah orang yang tidak berdaya karena tidak mempunyai pekerjaan apalagi penghasilan, dan juga mereka tidak mempunyai sanak saudara di bumi ini. Miskin ialah orang yang sudah memiliki penghasilan tapi tidak mencukupi pengeluaran kebutuhan mereka, tapi mereka masih mempunyai keluarga yang sekiranya masih mampu membantu mereka yang miskin ${ }^{3)}$

Peraturan Pemerintah Republik Indonesia (PP) Nomor 31 Tahun 1980 Tentang Penanggulangan Gelandangan Dan Pengemis Dalam Peraturan Pemerintah ini yang dimaksud dengan :

1. Gelandangan adalah orang-orang yang hidup dalam keadaan tidak sesuai dengan norma kehidupan yang layak dalam masyarakat setempat, serta tidak mempunyai tempat tinggal dan pekerjaan yang tetap di wilayah tertentu dan hidup mengembara di tempat umum.

2. Pengemis adalah orang-orang yang mendapatkan penghasilan dengan meminta-minta di muka umum dengan pelbagai cara dan alasan untuk mengharapkan belas kasihan dari orang lain.

Istilah gelandangan berasal dari kata gelandang yang berarti selalu mengembara, atau berkelana (lelana). Kemiskinan dapat disebabkan oleh kelangkaan alat pemenuh kebutuhan dasar, ataupun sulitnya akses terhadap pendidikan dan pekerjaan. Manusia sebagai salah satu ciptaan Tuhan Yang Maha Esa, sejak lahir dianugrahi akal dan fikiran yang berwujud didalam raga yang

1) Syafran Sofyan, Supremasi Hukum Dalam Rangka Mendukung Percepatan Daerah Tertinggal, makalah Kuliah Hukum dan HAM, Forkon Angkatan VI (Bupati, Walikota, Ketua DPRD) Lemhannas RI, Jakarta, 2012

2) Mochtar Kusumaatmadja Hukum, Masyarakat dan Pembinaan Hukum Nasional, Binacipta, hlm 9

${ }^{3)}$ Www.kompasiana.com/niko _ ramandhana/gepeng- anak-j alanan -pemerintah-dan-uud-1945-pasal-34-ayat1_54ff5aa6a333114e4a50ffa1 di akses pada tanggal 06-07-2018 
sempurna yang tersusun menjadi satu ke satuan tubuh dengan bentuk yang ideal dan proporsional untuk dapat melakukan berbagai macam aktivitas demi kelangsungan hidup ${ }^{4)}$

Pro kontra dalam Perundang-Undangan di Indonesia terlihat jelas ketika UUD 1945 melindungi fakir miskin dan anak terlantar sedangkan KUHP (Kitab Undang-Undang Hukum Pidana) melarang hal tersebut. Menurut Pasal 504 KUHP dengan tegas dijelaskan bahwa barang siapa mengemis di muka umum, diancam karena melakukan pengemisan dengan pidana kurungan paling lama enam minggu ${ }^{5}$.

Pengemisan semakin marak terjadi di kota kota besar dari tahun ke tahun di tambah lagi pada saat hari raya, peningkatan terjadi secara signifikan ada juga pengemis yang sudah di tangkap beberapa kali tetap kembali ke pekerjaan nya sebagai pengemis contoh bandung Gepeng (gelandangan pengemis) di Kota Bandung mengalami peningkatan sekitar 40 persen saat Ramadan. Kenaikan tersebut dikarenakan keinginan para Gepeng mengadu nasib di luar daerah asalnya menjelang lebaran. Kenaikan jumlah Gepeng selama Ramadan ${ }^{6}$ dan kasus pengemis di kota cirebon yang sudah berulang kali ditangkap tidak juga jera ${ }^{7)}$

\section{Identifikasi Masalah}

Berdasarkan latar belakang masalah diatas, maka penulis mengidentifikasi permasalahan sebagai berikut.:

1. Apa faktor penyebab tingginya angka tindak pidana pengemisan ?

2. Bagaimana upaya penegakan Pasal 504 dihubungkan dengan PP No 31 tentang penanggulangan gelandangan dan pengemis?

\section{TINJAUAN PUSTAKA}

Permasalahan gelandangan dan pengemis merupakan salah satu permasalahan sosial yang sulit untuk ditangani.Banyaknya jumlah gelandangan dan pengemis yang kerap kali terlihat memadati setiap perempatan dan ruas - ruas jalan utama bukan saja tidak sedap dipandang, melainkan menjadi isu serius yang perlu dicarikan jalan pemecahannya bersama.Selama ini keberadaan gelandangan dan pengemis (Gepeng) merugikan masyarakat dan negara.Negara dirugikan karena sumber daya manusia yang semula diharapkan dapat mandiri, produktif, dan mampu membangun negara menjadi gelandagan dan pengemis yang menggantungkan hidupnya kepada orang lain, tidak mempunyai kehidupan yang layak, dan tidak dapat mencukupi kebutuhan secara mandiri, serta kehidupannya bebas yang tidak mematuhi norma-norma.tidak sejalan dengan cita-cita nasional karena mereka menjadi beban Negara. Gepeng termasuk dalam golongan fakir miskin yang mana sesuai dengan UUD 1945 Pasal 34 ayat 1 berhak mendapakan perlindungan negara. Pemerintah mempunyai kewajiban dan bertanggungjawab untuk menyelesaikan permasalahan gelandangan dan pengemis supaya mereka dapat hidup dengan layak bersama masyarakat lainnya.pengaruhnya kemiskinan atas kejahatan. Orang kaya yang hanya hidup untuk kesenangan dan memboroskan kekayaannya, jika pada suatu kali jatuh miskin,

\footnotetext{
4) Soerjono Soekanto, Faktor-faktor Yang Mempengaruhi Penerapan sanksi, Raja Grafind o Persada, Jakarta: 1983, hlm. 1

${ }^{5}$ https:/gedesedana. wordpress.com /2009/07/28/faktor - penyebab - terjadinya - geland angan-danpengemis/ di akses pada tanggal 7-7-2018

${ }^{6} \mathrm{http} / /$ www.pikiranrakyat.com/bandungraya/2013/07/29/244653/jumlhgelandangan-pengemis-meningkat40-persen di akses pada tanggal 7-7-2018

${ }^{7)} \mathrm{http}$ :/www.radarcirebon.com/benang-kusut-penanganan- pgot-terciduk-tak-bikin-kapok.html di akses pada tanggal 7-7-2018
} 
mudah menjadi pencuri (de regime principum).Kemiskinan biasanya memberi dorongan untuk mencuri (summa contra gentiles).Yang juga menjadi menarik perhatian ialah pembelaan panjang lebar dari pada pendapatnya bahwa dalam keadaan yang sangat memaksa orang boleh mencuri (summa theological).pendapat yang dikemukakan, mendeskripsikan bahwa ada penyebab di luar kendali manusia sehingga cenderung melakukan kejahatan. dengan kata lain keadaan ekonomilah yang dapat menjadi penyebab sehingga orang memilih untuk melakukan kejahatan. Maka terkait dengan itu, secara sederhana pula sebenarnya dari penyebabnya orang melakukan kejahatan ${ }^{8)}$,

Gelandangan dan pengemis mayoritas tidak mempunyai identitas yang jelas, tidak memiliki kartu pengenal dan bahkan mereka memiliki banyak "topeng" ketika berada di jalanan.Hal ini menyebabkan susahnya melakukan pendataan kependudukan.Gelandangan dan pengemis juga mempunyai pola hidup yang bebas, mereka tidak terikat oleh aturan yang ada di mayarakat, mereka membuat aturan mereka sendiri bahkan cenderung menghiraukan nilai-nilai dan normanorma yang ada di masyarakat. Kehidupan gelandangan dan pengemis yang bebas membuat mereka betah berada di jalanan, mereka dapat melakukan hal-hal yang mereka inginkan meskipun itu melanggar nilai dan norma, contohnya melakukan hubungan seks bebas dan suka memungut barang milik orang. Keberadaan mereka diperburuk dengan terbentuknya keluarga gepeng (gelandangan dan pengemis), dimana gepeng ini dapat menjadi sebuah komunitas yang semua anggota keluarganya berprofesi sebagai gelandangan maupun pengemis. Selain itu, praktik penggelandangan dan pengemisan seperti gelandangan dengan pakaian compang-camping, kotor mengais-ais sampah untuk mencari makan, tidur sembarangan di emperan toko, jalan bahkan teras rumah orang, adapula pengemis yang meminta-minta padahal sebenarnya dia merupakan golongan orang mampu dan ada juga pengemis yang meminta belas kasihan dengan cara memaksa dapat mengganggu kenyamanan, ketertiban dan keamanan di lingkungan masyarakat, dan apabila tidak ditangani akan mengganggu stabilitas nasional.

Istilah "gepeng" merupakan singkatan dari kata gelandangan dan pengemis. Menurut Departemen Sosial R.I, gelandangan adalah orang-orang yang hidup dalam keadaan tidak sesuai dengan norma-norma kehidupan yang layak dalam masyarakat setempat serta tidak mempunyai tempat tinggal dan pekerjaan yang tetap di wilayah tertentu dan hidup mengembara di tempat umum.

Pengemis menurut Peraturan Pemerintah Republik Indonesia Nomor 31 Tahun 1980 Tentang Penanggulangan Gelandangan dan Pengemis adalah orang-orang yang mendapatkan penghasilan dengan meminta-minta di muka umum dengan berbagai cara dan alasan untuk mengharapkan belas kasihan dari orang lain. Permasalahan pengemis, dan gepeng, sebenarnya hanyalah turunan dari permasalahan kemiskinan. Selama persoalan kemiskinan belum teratasi jumlah pengemis, dan gepeng tidak akan pernah berkurang malah jumlahnya akan semakin bertambah.

Perilaku menggembel dan mengemis erat kaitannya dengan urbanisasi, dan urbanisasi erat kaitannya dengan adanya kesenjangan pembangunan wilayah pedesaan dan perkotaan. Semasih adanya kesenjangan ini maka urbanisasi akan sulit dibendung, dan akan memberi peluang munculnya kegiatan sektor informal seperti kegiatan menggembel dan mengemis. Kebijaksanaan penanggulangan gepeng yang dikembangkan adalah dengan lebih memacu pembangunan pedesaan agar serasi dengan pembangunan di daerah perkotaan.Pendekatan yang diperlukan adalah yang bersifat pendekatan holistik, yang tidak hanya terpaku pada pelaku gepeng itu sendiri tetapi berusaha menjangkau seluruh sub sistem yang mempengaruhi munculnya urbanisasi dan perilaku menggebel dan mengemis, serta termasuk seluruh sumberdaya manusia yang

\footnotetext{
${ }^{8)}$ Mr.w.a. Bonger “Pengantar tentang kriminologi” PT. pembangunan 1977 hlm 41
} 
ada.Sumberdaya manusia yang ada di pedesaan diusahakan untuk dikembangkan sebagai subyek pembangunan yang mampu memanfaatkan peluang yang ada serta mengembangkan potensi yang dimiliki dengan memperhatikan kendala yang dihadapi.

Peraturan Pemerintah Nomor 31 Tahun 1980 Pasal 2, kebijakan dibidang penanggulangan gepeng merupakan kebijakan yang telah ditetapkan oleh menteri berdasarkan pada kebijakan yang telah digariskan oleh pemerintah, dalam menetapkan kebijakan tersebut Menteri dibantu oleh sebuah badan koordinasi yang susunan, tugas dan wewenangnya diatur dengan keputusan peresiden. Penertiban gelandangan dan pengemis telah diatur dalam Kepres Nomor 40 tahun 1983 Tentang Koordinasi Penanggulangan Gelandangan dan Pengemis, dalam keputusan bersama antara Menteri Transmigrasi dan Pemukiman Perambah Hutan dan Menteri Sosial dengan nomor SKB. 102/MEN/1983 tentang penyelenggaraan Transmigrasi yang dikaitkan dengan penuntasan penyandang masalah kesejahteraan sosial.

Masalah kemiskinan di Indonesia berdampak negatif terhadap meningkatnya arus urbanisasi dari daerah pedesaan kekota-kota besar, sehingga terjadi kepadatan penduduk dan daerah-daerah kumuh yang menjadi pemukiman para urban tersebut, sulit dan terbatasnya pekerjaan yang tersedia serta terbatasnya pengetahuan, keterampilan dan pendidikan menyebabkan mereka banyak mencari nafkah untuk mempertahankan hidup dengan terpaksa menjadi gelandangan dan pengemis. Kementerian Sosial terus berupaya untuk mengurangi tingkat populasi Gepeng atau gembel dan pengemis, tahun 2011 pemerintah berusaha untuk lebih mengedepankan upaya penanggulangan kedua pokok permasalahan tersebut, di Indonesia terdapat sekitar 30 juta orang penyandang masalah kesejahteraan sosial (PMKS), yang terbagi dalam 22 kelompok, salah satunya adalah gelandangan, dan pengemis (gepeng) yang jumlahnya sekitar 3 juta jiwa.

Maraknya jumlah gelandangan dan anak-anak jalanan di tengah- tengah kota besar tentu mengindikasikan meningkatnya tingkat kemiskinan kota yang pada akhirnya mengemis dan jadi gelandangan bukan nasib tapi pilihan mereka. Namun hakekatnya persoalan mereka bukanlah kemiskinan belaka, melainkan juga eksploitasi, manipulasi, ketidakkonsistenan terhadap caracara pertolongan baik oleh mereka sendiri maupun pihak lain yang menaruh perhatian terhadap Anak Jalanan dan Gepeng.

Gepeng atau "gembel dan pengemis" bukanlah sebuah prestasi atau pilihan hidup namun lebih mengarah kepada tuntutan hidup yang dipengaruhi oleh kurangnya pengetahuan dan keterampilan serta tidak dapat melaksanakan fungsi sosialnya sehingga tidak dapat terpenuhi kebutuhan hidupnya secara memadai dan wajar. ${ }^{9)}$

Penegakan hukum merupakan suatu usaha untuk mewujudkan ide-ide keadilan, kepastian hukum dan kemanfaatan sosial menjadi kenyataan. Jadi penegakan hukum pada hakikatnya adalah proses perwujudan ide-ide, Penegakan hukum adalah proses dilakukannya upaya tegaknya atau berfungsinya norma-norma hukum secara nyata sebagai pedoman pelaku dalam lalu lintas atau hubungan-hubungan hukum dalam kehidupan bermasyarakat dan bernegara. Penegakan hukum merupakan usaha untuk mewujudkan ide-ide dan konsep-konsep hukum yang diharapakan rakyat menjadi kenyataan. Penegakan hukum merupakan suatu proses yang melibatkan banyak hal ${ }^{10)}$

${ }^{9}$ http://sumber-ilmu-islam .blogspot.com /2014/01/pengertian- gembel- dan-pengemis-gepeng.html diakses pada tanggal 10-7-2-18

10) Dellyana,Shant.1988,Konsep Penegakan Hukum. Yogyakarta: Liberty hlm 32 
Penegakan hukum adalah kegiatan menyerasikan hubungan nilai-nilai yang terjabarkan didalam kaidah kaidah/pandangan nilai dan sikap tindakan sebagai rangkaian penjabaran nilai tahap akhir untuk menciptakan, memelihara dan mempertahankan kedamaian pergaulan hidup.

Peraturan Pemerintah Republik Indonesia (PP) Nomor 31 Tahun Gepeng memerlukan perbaikan mental khususnya jenis gelandangan psikotik yang mana kejiwaannya terganggu. Perbaikan bagi gelandangan dan pengemis yang sehat secara fisik dan kejiwaannya dapat dilakukan dengan cara brainwashing untuk membuka pemikiran dan merubah pola pikir Gepeng yang semula "tangan di bawah" menjadi "tangan di atas lebih baik daripada tangan di bawah", sehingga mereka dapat menghentikan pencarian nafkah melalui kegiatan menggelandang dan mengemis lalu berganti dengan cara bekerja sesuai nilai-nilai dan norma.Perbaikan mental saja tidaklah cukup untuk membantu gelandangan agar dapat hidup dengan baik dan layak.

Perbaikan mental harus disertai dengan pemberian pendidikan dan pelatihan.Pendidikan merupakan kebutuhan dasar manusia dan bersifat sepanjang hayat.Pendidikan dapat dilaksanakan oleh siapa saja, dimana saja, dankapan saja.Pendidikan merupakan hak asasi seluruh umat manusia tak terkecuali bagi gelandangan dan pengemis.Hal ini sesuai dengan amanat UUD 1945 Pasal 31 ayat (1) yang menyebutkan bahwa setiap warga negara berhak mendapatkan pendidikan.Pendidikan bagi gelandangan dapat ditempuh melalui pendidikan jalur non formal atau biasa disebut pendidikan non formal/pendidikan luar sekolah melalui lembaga pemerintahan maupun non pemerintahan. Pendidikan dan pelatihan bagi gelandangan dan pengemis (Gepeng) sangatlah diperlukan karena dengan memperoleh pendidikan dan pelatihan, mereka dapat memperoleh pengetahuan dan ketrampilan yang sesuai dengan kebutuhan yang dapat dijadikan modal untuk bekerja secara layak sehingga mereka mampu meningkatkan kualitas hidupnya.

Penanggulangan Gelandangan Dan Pengemis yang di lakukan pemerintah antar lain.

1. Usaha preventif adalah usaha secara terorganisir yang meliputi penyuluhan, bimbingan, latihan, dan pendidikan, pemberian bantuan, pengawasan serta pembinaan lanjut kepada berbagai pihak yang ada hubungannya dengan pergelandangan dan pengemisan, sehingga akan tercegah terjadinya:

a. Berada dalam keadaan sulit penghidupannya;

b. Meluasnya pengaruh dan akibat adanya pergelandangan dan pengemisan di dalam masyarakat yang dapat mengganggu ketertiban dan kesejahteraan pada umumnya;

c. Pergelandangan dan pengemisan kembali oleh para gelandangan dan pengemis yang telah direhabilitasi dan telah ditransmigrasikan ke daerah pemukiman baru ataupun telah dikembalikan ke tengah masyarakat.

2. Usaha represif adalah usaha-usaha yang terorganisir, baik melalui lembaga maupun bukan dengan maksud menghilangkan pergelandangan dan pengemisan, serta mencegah meluasnya di dalam masyarakat.

3. Usaha rehabilitasi adalah usaha-usaha yang terorganisir meliputi usaha-usaha penyantunan, pemberian latihan dan pendidikan, pemulihan kemampuan dan penyaluran kembali baik ke daerah-daerah pemukiman baru melalui transmigrasi maupun ke tengah-tengah masyarakat, pengawasan serta pembinaan lanjut, sehingga dengan demikian para gelandangan dan pengemis, kembali memiliki kemampuan untuk hidup secara layak sesuai dengan martabat manusia sebagai Warga negara Republik Indonesia. 


\section{PEMBAHASAN}

\section{Faktor-Faktor Terkait Kasus Meningkat Nya Pengemisan}

Selama bulan Ramadhan pengemisan yang terjadi di bandung mengalami kenaikan karena selama bulan Ramadhan banyak umat muslim yang bersedekah untuk mendapatkan pahala, itu salah satu kondisi yang di manfaatkan oleh pengemis baik dari kota bandung, maupun luar kota bandung, pengemis memanfaatkan bulan suci bagi umat muslim untuk mendulang uang yang diberikan oleh umat muslim sebagai infaq dan zakat kepada fakir miskin.

Ciri-ciri pengemis di antara nya seperti, pakaian yang dikenakan compang camping, kondisi tubuh yang cacat, ada yang memang benar-benar cacat tapi juga ada yang tidak, biasa nya pengemisan dilakukan di pinggir jalan raya, trotoar, jembatan, perempatan lampu merah, kawasan pusat perbelanjaan dan pasar tradisional. Pengemis adalah orang-orang yang mendapatkan penghasilan dengan meminta-minta di muka umum dengan berbagai cara dan alasan untuk mengharapkan belas kasihan dari orang lain Gelandangan adalah orang-orang yang hidup dalam keadaan tidak sesuai dengan norma kehidupan yang layak dalam masyarakat setempat, serta tidak mempunyai tempat tinggal dan pekerjaan yang tetap di wilayah tertentu dan hidup mengembara di tempat umum.

Pengemisan terjadi karena beberapa faktor di antara nya faktor internal dan faktor eksternal. Faktor internal meliputi sifat-sifat malas, tidak mau bekerja, mental pengemis yang menganggap pengemisan merupakan pekerjaan yang sudah biasa dan tidak malu untuk mengemis, padahal pengemisan merupakan pekerjaan yang tidak baik dan tidak sesuai dengan cita-cita Negara Indonesia untuk mensejahterakan bangsa, adanya cacat fisik ataupun cacat psikis. Sedangkan faktor eksternal meliputi faktor sosial yang bebarapa pengemis ataupun gelandangan di pengaruhi oleh teman-teman nya yang sudah terlebih dahulu melakukan pengemisan, kultural, ekonomi, pendidikan, lingkungan, letak geografis. Pengemisan merupakan perilaku kriminal yang dilakukan dengan melanggar norma-norma masyarakat termasuk norma hukum perbuatanperbuatan anti sosial, perilaku kriminal terjadi dalam pergaulan dengan mereka yang melakukan kejahatan, yang berarti dalam relasi langsung di tengah pergaulan, termasuk didalamnya teknik melakukan kejahatan dan motivasi/ dorongan atau alasan pembenar, Dorongan tertentu ini melalui penghayatan atas peraturan perundang-undangan menyukai atau tidak menyukai, karena penghayatannya terhadap peraturan perundangan lebih suka melanggar daripada mentaatinya, sebagai konsekuensi logis kegagalan seseorang untuk mengembangkan larangan-larangan ke dalam terhadap perilaku melanggar hukum. Pengemis kebanyakan tidak memiliki keahlian lain untuk mendapat pekerjaan yang layak dan lebih memilih mengemis sebagai perkerjaan nya. Juga ada pengemis yang terkordinasi dalam suatu sindikat. Dengan dikordinasi oleh seseorang yang dianggap bos, setiap pengemis "anggota" wajib menyetor hasil mengemisnya kepada sindikat, baik secara harian, mingguan atau bulanan.

\section{UPAYA PENEGAKAN PASAL 504 DIHUBUNGKAN DENGAN PP NO 31 TENTANG PENANGGULANGAN GELANDANGAN DAN PENGEMIS}

Pengemisan merupakan pekerjaan yang tidak sesuai dengan cita-cita Negara indoesia yaitu mensejahterakan rakyat, karena selain akan terlihat kumuh pengemis juga rentan terhadap kejahatan untuk itu pemerintah perlu membuat peraturan untuk menanggulangi nya, dengan begitu di harap kan pengemisan bisa di tiadakan. Tetapi walaupun sejak di sahkan nya peraturan mengenai penanggulangan pengemis, pengemisan tetap saja terjadi di Indonesia. 
Penegakan hukum merupakan suatu usaha untuk mewujudkan ide-ide keadilan, kepastian hukum dan kemanfaatan sosial menjadi kenyataan. Jadi penegakan hukum pada hakikatnya adalah proses perwujudan ide-ide. Penegakan hukum adalah proses dilakukannya upaya tegaknya atau berfungsinya norma-norma hukum secara nyata sebagai pedoman pelaku dalam lalu lintas atau hubungan-hubungan hukum dalam kehidupan bermasyarakat dan bernegara. Penegakan hukum merupakan usaha untuk mewujudkan ide-ide dan konsepkonsep hukum yang diharapakan rakyat menjadi kenyataan. Penegakan hukum merupakan suatu proses yang melibatkan banyak hal

Bila dikaitkan dengan kasus yang telah diuraikan dalam bab sebelumnya yaitu kasus pengemis yang tidak kapok meskipun sudah beberapa kali di razia oleh petugas, Untuk mencegah meluasnya dan bertambahnya kejahatan yang melanggar nilai-nilai maupun norma-norma yang hidup dan berlaku di dalam suatu masyarakat, maka tentu saja sangat diperlukan upaya-upaya penanggulangan.

Langkah penanggulangan kejahatan (criminal prevention) emperik terdiri atas Upaya preemtif adalah upaya-upaya awal yang dilakukan oleh pihak kepolisian untuk mencegah terjadinya tindak pidana.Usaha rehabilitatif terhadap gelandangan dan pengemis meliputi usaha-usaha penampungan, seleksi, penyantunan, penyaluran dan tindak lanjut, bertujuan agar fungsi sosial mereka dapat berperan kembali sebagai warga masyarakat. usaha rehabilitatif dilaksanakan melalui Panti Sosial Tata cara pelaksanaan ketentuan sebagaimana dimaksud diatur lebih lanjut oleh Menteri sesuai dengan peraturan perundang-undangan yang berlaku.Usaha penampungan ditujukan untuk meneliti/menyeleksi gelandangan dan pengemis yang dimasukkan dalam Panti Sosial.Seleksi bertujuan untuk menentukan kualifikasi pelayanan sosial yang akan diberikan. penyantunan ditujukan untuk mengubah sikap mental gelandangan dan pengemis dari keadaan yang non produktif menjadi keadaan yang produktif gelandangan dan pengemis diberikan bimbingan, pendidikan dan latihan baik fisik, mental maupun sosial serta keterampilan kerja sesuai dengan bakat dan kemampuannya, usaha penyaluran ditujukan kepada gelandangan dan pengemis yang telah mendapatkan bimbingan, pendidikan, latihan dan keterampilan kerja dalam rangka pendayagunaan mereka terutama ke sektor produksi dan jasa, melalui jalur-jalur transmigrasi swakarya, dan pemukiman lokal.pre-emtif adalah menanamkan nilai-nilai atau norma-norma yang baik sehingga norma-norma tersebut terinternalisasi dalam diri seseorang. Meskipun ada kesempatan melakukan pelanggaran atau kejahatan tetapi tidak ada niatnya untuk melakukan hal tersebut maka tidak akan terjadi kejahatan. Jadi dalam usaha pre-emtif, faktor niat menghilang meski ada kesempatan. Upaya preventif merupakan tindak lanjut dari usaha preemtif yang masih dalam tataran pencegahan sebelum terjadinya kejahatan. Dalam upaya preventif, yang ditekankan adalah menghilangkan kesempatan untuk dilakukannya kejahatan. Contoh, ada orang yang berniat mencuri uang di bank tetapi kemudian batal sebab disana rupanya dia melihat banyak satpam yang hilirmudik memperketat penjagaan. Jadi dalam upaya preventif kesempatan ditutup.

Beberapa upaya penangulangan kejahatan dengan cara non konvensional yaitu:Pemantapan aparat penegak hukum dan jajarannya, Pemantapan hukum dan perundangan, Pemantapan sistem peradilan, Forum kordinatif antara praktisi hukum seperti penasehat hukum, jaksa, hakim dengan intansi terkait seperti lembaga pendidikan, pemerintahan dan organisasi kemasyarakatan, Pemberdayaan masyarakat dalam wujud pengamanan swakarsa lingkungan 


\section{KESIMPULAN}

Berdasarkan hasil penelitian maka dapat di simpulkan:

1. Kurang nya perhatian pemerintah terkait pengemisan di muka umum, dan tidak tegas nya penegakan hukum berdampak pada semakin marak nya gelandangan dan pengemisan di muka umum di butuhkan pengawasan terhadap pengemis, serta sanksi yang di nilai kurang berat menyebabkan pengemis tidak jera dan terus mengulangi perbuatan nya tersebut untuk itu pemerintah seharusnya menegakan lagi PP no 31 tahun 1980 tentang penanggulangan gelandangan dan pengemis karena dalam PP tersebut sudah jelas tentang apa dan bagaimana penanggulangan gelandangan dan pengemis, hanya tinggal di tingkatkan saja soal penegakan PP tersebut, di barengi sanksi tegas Pasal 504 KUHP.

2. Upaya dalam penanggulangan gelandangan dan pengemisan di muka umum yang yang di lakukan pemerintah terdapat pada PP no 31 tahun 1980 tentang penanggulangan gelandangan dan pengemis yaitu usaha represif, rehabilitasi, dan rehabilitative, dimana usaha represif adalah usaha-usaha yang terorganisir, baik melalui lembaga maupun bukan dengan maksud menghilangkan pergelandangan dan pengemisan, serta mencegah meluasnya di dalam masyarakat. Usaha sebagaimana dimaksud Pasal 5, terdapat dalam Pasal selanjutnya yaitu Pasal 6 antara lain dengan Penyuluhan dan bimbingan sosial, Pembinaan sosial, Bantuan sosial, Perluasan kesempatan kerja, Pemukiman lokal, dan Peningkatan derajat kesehatan.Usaha rehabilitasi adalah usaha-usaha yang terorganisir meliputi usaha-usaha penyantunan, pemberian latihan dan pendidikan, pemulihan kemampuan dan penyaluran kembali baik ke daerah-daerah pemukiman baru melalui transmigrasi maupun ke tengah-tengah masyarakat, pengawasan serta pembinaan lanjut, sehingga dengan demikian para gelandangan dan pengemis, kembali memiliki kemampuan untuk hidup secara layak sesuai dengan martabat manusia sebagai Warga negara Republik Indonesia. Usaha tindak lanjut ditujukan kepada gelandangan dan pengemis yang telah disalurkan, agar mereka tidak kembali menjadi gelandangan dan pengemis, usaha tindak lanjut sebagaimana dimaksud antara lain dilakukan dengan Meningkatkan kesadaran berswadaya, Memelihara, memantapkan dan meningkatkan kemampuan sosial ekonomi, Menumbuhkan kesadaran hidup bermasyarakat

\section{SARAN}

Berdasarkan kesimpulan diatas, maka Penulis menyarankan sebagai berikut

1. Penegakan hukum terhadap pengemis di muka umum berdasarkan pasal 504 KUHP dan PP no 31 tahun 1980 tentang penaggulangan pengemis dan gelandangan, seharus nya dimulai dari penegak hukum yang bekerja sebagai pelaksana, haruslah bekerja dengan baik sebagai mana mestinya agar tercapainya keadilan dan kepastian hukum, serta melakukan pengawasan berkala dengan cara merazia dan mempertegas sanksi .

2. Kedepan nya pengemis mendapatkan penyuluhan dan pembinaan agar mereka tahu bahwa perbuatan mengemis adalah perbuatan melanggar hukum dan dapat dikenakan sanksi pidana untuk yang melanggar serta dibina agar mereka mendapat pekerjaan yang lebih layak. Lalu Masyarakat sebagai pihak pemberi sumbangan kepada pengemis seharusnya lebih memperhatikan sekitar untuk membantu dan sebaiknya memberi langsung ketempat-tempat yang tepat seperti panti asuhan dan lain-lain. Untuk pengemis yang sudah tertangkap dan terus beruang kali melakukan pengemisan di muka umum maka berdasarkan PP No 31 tahun 1980 tentang gelandangan dan pengemis Pasal 12 huruf d, di sebutkan penyerahan ke Pengadilan bagi yang diduga melakukan penggelandangan dan pengemis sebagai mata pencahariannya dan atau yang diduga telah berulangkali melakukan perbuatan tersebut. 
Menurut pasal 504 KUHP ayat 1(satu) barang siapa mengemis di muka umum, diancam karena melakukan pengemisan dengan pidana kurungan paling lama enam minggu. Dengan di berlakukan kan nya KUHP maka diharapkan tidak ada lagi pengemis yang akan berulangkali di tangkap, di sini lah peran serta penegak hukum di perlukan untuk memberikan sanksi tegas kepada pelanggar.

\section{DAFTAR PUSTAKA}

Mochtar Kusumaatmadja Hukum, Masyarakat dan Pembinaan Hukum Nasional, Binacipta

Soerjono Soekanto, Faktor-faktor Yang Mempengaruhi Penerapan sanksi, Raja Grafind o Persada, Jakarta: 1983,

Syafran Sofyan, Supremasi Hukum Dalam Rangka Mendukung Percepatan Daerah Tertinggal, makalah Kuliah Hukum dan HAM, Forkon Angkatan VI (Bupati, Walikota, Ketua DPRD) Lemhannas RI, Jakarta, 2012

https://gedesedana. wordpress.com /2009/07/28/faktor - penyebab - terjadinya - geland angandan-pengemis/

http://www.pikiranrakyat.com/bandungraya/2013/07/29/244653/jumlhgelandangan-pengemismeningkat-40-persen

www.kompasiana.com/niko _ ramandhana/gepeng- anak-j alanan -pemerintah-dan-uud-1945pasal-34-ayat-1_54ff5aa6a333114e4a50ffa1

http://www.radarcirebon.com/benang-kusut-penanganan- pgot-terciduk-tak-bikin-kapok.html 